\title{
Microbial Flora, Proximate Composition and Vitamin Content of Juices of Three Fruits Bought from a Local Market in Nigeria
}

\author{
Ositadinma C. Ugbogu and Alloysius C. Ogodo
}

\begin{abstract}
Microbial flora, proximate composition and vitamin content of juices of three fruits bought from a local market in Nigeria were investigated. The assessment of the yeast and bacteria flora of the juices of the fruits revealed the presence of Candida pseudotropicalis, Candida tropicalis, Saccharomyces cerevisiae, Trichosporon asashii, Rhodotorula glutinis, Erwinia herbicola, Serratia species, Staphylococcus saprophyticus, Enterococcus faecium and Leuconostoc species. Candida pseudotropicalis and Saccharomyces cerevisiae were present in all the test fruits, Candida tropicalis was present in watermelon and banana, Trichosporon asashii was present in pawpaw, watermelon while Rhodotorula glutinis was present in pawpaw fruit only. Erwinia herbicola was present in pawpaw and banana, Serratia species was present in pawpaw and watermelon while Staphylococcus saprophyticus was isolated from all the test fruits. The proximate analysis of the test fruits revealed them to be poor sources of protein but with high moisture content that ranged from $76.92 \pm 0.04 \%$ to $92.93 \pm 0.10 \%$. The carbohydrate content ranged from $4.89 \pm 0.03 \%$ to $21.76 \pm 0.02 \%$. The analysis of vitamins showed that the test fruits were good sources of vitamin A, B1, B2, C, D, E and K with values ranging from $0.009 \pm 0.01 \mathrm{mg} / 100 \mathrm{~g}$ for vitamin $D$ in banana to $45.4 \pm 0.02 \mathrm{mg} / 100 \mathrm{~g}$ for vitamin $C$ in pawpaw fruit.
\end{abstract}

Index Terms-Fruits, juices, microbial flora, proximate composition, vitamins.

\section{INTRODUCTION}

Banana (Musa sapientum) is a herbacius plant in the family Musaceae. It is native to tropical South-eastern Asia and widely cultivated in tropical region, Nigeria inclusive [1]. It is an important staple starchy food in Nigeria. Ripe bananas are consumed raw as a desert fruit. However, banana is a seasoned crop and the shelf-life is short under the prevailing temperature and humidity condition in tropical countries [2] including Nigeria. Following maturation and harvest, there is a rapid rate of deterioration of ripe bananas. Bananas serves as good nutritional sources of carbohydrates, minerals such as potassium and vitamins such as B1, B2, B3, B12, C and E [3]. Following the high nutritional content of banana, it is consumed in large quantity in variety of ways in Africa [4]-[6]. Though consumed to a considerable extend, large quantities of ripe bananas are usually wasted as a result of poor handling and inadequate storage facilities. Therefore, method to extend the shelf-life of banana will be useful. However, fermenting banana juice is considered to be an attractive means of

Manuscript received December 11, 2014; revised March 19, 2015.

The authors are with the Microbiology Department, Faculty of Pure and Applied Science, Federal University Wukari, P.M.B. 1020, Wukari, Taraba State, Nigeria (e-mail: ositadinmacu@fuwukari.edu.ng, alloysiuschibuike@yahoo.com). utilizing surplus and overripe banana [3].

Pawpaw (Carica papaya) is grown mostly for fresh consumption or for production of latex. Pawpaw fruit is a good source of carbohydrate, vitamins ( $\mathrm{C}$ and $\mathrm{A}$ ) and minerals (copper and magnesium) [7]-[9]. Fresh papaw fruits are very perishable, thereby making their exports problematic. Large quantities of pawpaw are disposed off yearly due to lack of or poor storage facilities. This results to loss of the vital nutrients (vitamin) contained in the pawpaw fruits and revenue obtained from their sale [10]. However these losses can be reduced and pawpaw can be made available all year round, by utilizing the fruits for other purposes such as wine production.

Watermelon (Citrullus vulgaris L.) is a tropical fruit which grows in almost all parts of Africa including Nigeria and South East Asia [11]. It is a good source of vitamins and often used as an appetizer or snack, depending on how it is prepared [12]. It also serves as a good source of phytochemical and lycopene; a red carotenoid pigment which acts as antioxidant during normal metabolism and protects against cancer [13], [14]. However, large quantities of watermelon are wasted as a result of poor storage facilities and conditions. In Nigeria, watermelon are fermented, blended and consumed as juice [12], [15].

This paper reports the microbial flora, proximate composition and vitamin content of juices of three fruits bought from a local market in Nigeria.

\section{MATERIALS AND METHODS}

\section{A. Source of Materials}

Banana (Musa acuminata), pawpaw (Carica papaya L), and watermelon (Citrullus vulgaris $L$.) were purchased from the local central market (Nkwo Achara) in Uturu, Abia State, Nigeria. The fruits were transported to the laboratory in clean cellophane bags for analysis.

\section{B. Assessment of the Yeasts Flora of the Fruits Juices}

The yeasts flora of the fruits were assessed by culturing the juice obtained after crushing the fruits using an electric laboratory blender (Binatone) on Potato Dextrose Agar (PDA) and incubating at room temperature for 48 hours to determine the indigenous yeast communities harboured by the fruits. On establishment of growth, the yeasts isolates were sub-cultured on fresh medium to obtain pure cultures. The yeasts isolated were characterised based on their cultural characteristics, microscopy and sugar fermentation tests and with reference to [16].

\section{Assessment of the Bacteria Flora of the Fruits Juices}

The bacteria flora of the fruits was determined as the type 
of bacteria that colonized the juice of the test fruits on analysis described below. Exactly $0.5 \mathrm{ml}$ of each of the fruits juice was cultured on Nutrient agar (NA) and MacConkey Agar (MA) using the spread plate method according to the method of [17]. On the establishment of growth after 24 hours of incubation, each cultured plate was examined closely for distinct colonies from which inocula were taken and subcultured in a fresh sterile, nutrient agar plates. Subsequent cultures were incubated at room temperature and observed after 24 hours for pure cultures. The pure cultures obtained above were identified using a four step characterization process reported by [18] and [19].

\section{Proximate Analysis of the Fruits}

The proximate analysis of the fruits for fermentation was done to determine the moisture content, ash content, protein content, lipid content, crude fibre and carbohydrate contents. The moisture content of the fruits (pawpaw, banana and watermelon) was determined using evaporation method as described by [20].

The ash content was determined using the dry ashing method [20]. This method uses a high temperature muffle furnace capable of maintaining temperatures between 500 and $600^{\circ} \mathrm{C}$. Water and other volatile materials are vapourized and organic substances are burned in the presence of oxygen in the air to $\mathrm{CO}_{2}, \mathrm{H}_{2} \mathrm{O}$ and $\mathrm{N}_{2}$. Most materials are converted to oxides, sulphates, phosphates, chlorides or silicates.

The overall protein content was determined using the Kjedahl method while the lipid content of the samples was determined using the Soxhlet method as described by [20].

The fibre content of the fruits was determined using the methods described by [21]. While the carbohydrate contents of the samples were determined using the Lane and Eynon method [21].

\section{E. Determination of the Vitamin Composition of the Fruits}

The analysis of the vitamin compositions of the fruits for fermentation was done to determine the content of vitamin $\mathrm{A}, \mathrm{D}, \mathrm{E}, \mathrm{K}, \mathrm{C}, \mathrm{B} 1$, and vitamin B2. Vitamin A, C and vitamin $\mathrm{E}$ were extracted and quantified accordingly to the method described by [22]. Vitamin D was quantitatively determined using liquid chromatography according to the method of [23]. Vitamin K and vitamin B1 was determined using the method of [24] while Vitamin B2 (Riboflavin) was extracted according to the method described in [25].

\section{RESULTS}

The assessment of the yeast and bacteria flora of the fruits revealed the presence of Candida pseudotropicalis, Candida tropicalis, Saccharomyces cerevisiae, Trichosporon asashii, Rhodotorula glutinis, Erwinia herbicola, Serratia species, Staphylococcus saprophyticus, Enterococcus faecium and Leuconostoc species (Table I). Candida pseudotropicalis and Saccharomyces cerevisiae were present in all the test fruits , Candida tropicalis was present in watermelon and banana, Trichosporon asashii was present in pawpaw and watermelon while Rhodotorula glutinis was present in pawpaw fruit only. Erwinia herbicola was present in pawpaw and banana Serratia species was present in watermelon and pawpaw while Staphylococcus saprophyticus was isolated from all the test fruits.

Proximate analysis showed that the test fruits (pawpaw, banana and watermelon) were poor sources of protein with values ranging from $0.56 \pm 0.02 \%$ for banana to $1.22 \pm 0.02 \%$ for watermelon, but with high moisture content that ranged from $76.92 \pm 0.04 \%$ for banana to $92.93 \pm 0.10 \%$ for watermelon (Table II). The highest moisture and protein contents were observed in watermelon $(92.93 \pm 0.10 \%)$, followed by pawpaw $(88.89 \pm 0.04 \%)$ and then banana $(76.92 \pm 0.02 \%)$. The result also revealed that the highest carbohydrate content was observed in banana fruit $(21.76 \pm 0.02 \%)$ followed by pawpaw fruit $(8.80 \pm 0.02 \%)$ while the least carbohydrate content was observed in watermelon fruit $(4.89 \pm 0.03 \%)$.

The test fruits (pawpaw, banana and watermelon) were good sources of vitamin $\mathrm{C}$ with values ranging from $5.2 \pm 0.02 \mathrm{mg} / 100 \mathrm{~g}$ for watermelon to $45.4 \pm 0.03 \mathrm{mg} / 100 \mathrm{~g}$ for pawpaw but with low vitamin $\mathrm{D}, \mathrm{B} 1$ and $\mathrm{B} 2$ in the range of $0.009 \pm 0.01 \mathrm{mg} / 100 \mathrm{~g}$ to $0.04 \pm 0.01 \mathrm{mg} / 100 \mathrm{~g}$ (Table III). The highest vitamin $\mathrm{C}$ content was observed in pawpaw $(45.4 \pm 0.03 \mathrm{mg} / 100 \mathrm{~g})$ followed by banana $(12.00 \pm 0.02 \mathrm{mg} / 100 \mathrm{~g})$ and then watermelon $(5.20 \pm 0.02 \mathrm{mg} / 100 \mathrm{~g})$. The result also show that the highest vitamin A content was observed in watermelon $(8.65 \pm 0.02 \mathrm{mg} / 100 \mathrm{~g})$ followed by pawpaw $(2.90 \pm 0.03 \mathrm{mg} / 100 \mathrm{~g})$ and then banana $(0.17 \pm 0.02 \mathrm{mg} / 100 \mathrm{~g})$ while vitamin $\mathrm{D}, \mathrm{E}, \mathrm{K}, \mathrm{B} 1$ and $\mathrm{B} 2$ were observed in small amounts ranging from $0.009 \pm 0.02 \mathrm{mg} / 100 \mathrm{~g}$ for vitamin $\mathrm{D}$ in banana to $0.34 \pm 0.03 \mathrm{mg} / 100 \mathrm{~g}$ for vitamin $\mathrm{E}$ in watermelon.

\begin{tabular}{lccc}
\multicolumn{5}{c}{ TABLE I: OCCURRENCE OF YEASTS AND BACTERIA IN THE FRUIT SAMPLES } \\
\hline \multicolumn{1}{c}{ Organisms } & $\begin{array}{l}\text { Waterme } \\
\text { lon }\end{array}$ & Pawpaw & Banana \\
& + & & \\
\hline Candida pseudotropicalis & + & + & + \\
Candida tropicalis & + & - & + \\
Saccharomyces cerevisiae & + & + & + \\
Trichosporon asashii & + & + & - \\
Rhodotorula glutinis & - & + & - \\
Erwinia herbicola & - & + & + \\
Serratia species & + & + & + \\
Staphylococcus & + & + & + \\
saprophyticus & & & + \\
Enterococcus faecium & + & - & \\
\hline Key: + Positive, & & & +
\end{tabular}

Key: + = Positive, - = Negative

TABLE II: PROXIMATE COMPOSITIONS OF THE FRUITS

\begin{tabular}{cccc}
\hline Composition (\%) & Watermelon & Pawpaw & Banana \\
\hline Moisture & $92.93 \pm 0.10$ & $88.89 \pm 0.04$ & $76.92 \pm 0.04$ \\
Ash content & $0.94 \pm 0.02$ & $0.27 \pm 0.03$ & $0.16 \pm 0.02$ \\
Protein & $1.22 \pm 0.03$ & $0.94 \pm 0.03$ & $0.56 \pm 0.02$ \\
Lipid content & $0.48 \pm 0.03$ & $0.78 \pm 0.03$ & $0.59 \pm 0.02$ \\
Fibre content & $0.10 \pm 0.02$ & $0.31 \pm 0.02$ & $0.02 \pm 0.01$ \\
Carbohydrate & $4.89 \pm 0.03$ & $8.80 \pm 0.02$ & $21.76 \pm 0.02$ \\
\hline
\end{tabular}

Key: \% = Percentage

Values are the mean \pm SD of three replicate. 
TABLE III: VITAMIN COMPOSITION OF THE FRUITS

\begin{tabular}{llcc}
\hline $\begin{array}{l}\text { Vitamins } \\
(\mathbf{m g} / \mathbf{1 0 0 g})\end{array}$ & Watermelon & Pawpaw & Banana \\
\hline Vitamin A & $8.65 \pm 0.02$ & $2.90 \pm 0.03$ & $0.17 \pm 0.03$ \\
Vitamin B1 & $0.045 \pm 0.02$ & $0.042 \pm 0.02$ & $0.05 \pm 0.02$ \\
Vitamin B2 & $0.04 \pm 0.01$ & $0.13 \pm 0.01$ & $0.13 \pm 0.02$ \\
Vitamin C & $5.20 \pm 0.02$ & $45.4 \pm 0.03$ & $12.00 \pm 0.02$ \\
Vitamin D & $0.02 \pm 0.01$ & $0.08 \pm 0.01$ & $0.009 \pm 0.01$ \\
Vitamin E & $0.34 \pm 0.03$ & $0.20 \pm 0.02$ & $0.05 \pm 0.02$ \\
Vitamin K & $0.15 \pm 0.02$ & $0.05 \pm 0.02$ & $0.05 \pm 0.02$ \\
\hline
\end{tabular}

Key: $\mathrm{mg} / 100 \mathrm{~g}=$ milligram per 100 grams

Values are the mean \pm SD of three replicate.

\section{DISCUSSION}

In the present study the Microbial flora, proximate composition and vitamin content of juices of three fruits bought from a local market in Nigeria were investigated. The assessment of the yeast and bacteria flora of the fruits revealed the presence of Candida pseudotropicalis, Candida tropicalis, Candida utilis, Candida crusei, Saccharomyces cerevisiae, Trichosporon asashii, Rhodotorula glutinis, Erwinia herbicola, Serratia species, Staphylococcus saprophyticus, Enterococcus faecium and Leuconostoc species. Candida pseudotropicalis and Saccharomyces cerevisiae were present in all the test fruits, Candida tropicalis was present in watermelon and banana, Trichosporon asashii was present in pawpaw, watermelon and while Rhodotorula glutinis was present in pawpaw fruit only. Erwinia herbicola was present in pawpaw, banana while Staphylococcus saprophyticus was isolated from all the test fruits. Similar observation was reported by [17], [26] and [10] who isolated similar organisms from banana, watermelon and pawpaw respectively. However, the microorganisms isolated in this study have largely been associated with materials from which they were recovered [17], [27].

The proximate composition of the test fruits compared favourably with the reports of [2], [26] and [28] for watermelon, banana and pawpaw respectively. The low protein content of the fruits as reported in this study is a probable indication that the fear of accumulation due to consumption of the fruits do not arise.

From the results, the mean moisture content of the fruits ranged from $76.92 \pm 0.04 \%$ in banana to $92.93 \pm 0.10 \%$ in watermelon. This accounts for their high perishable nature and their short life span under normal storage conditions [26]. The fruits contained reasonable amounts of carbohydrate, which gives an account of their high caloric value and indication. The lipids contents of banana fruit are in agreement with the reports that banana fruits contain traces of fat [1].

The vitamin composition of the test fruits (pawpaw banana and watermelon) compared favourably with the reports of [29] and [30] for watermelon, [8] and [31] for pawpaw and [7] for banana. Also the result supported the assertion that these fruits are good sources of vitamin $\mathrm{C}, \mathrm{A}$ and $\mathrm{K}[7]$.
The values of vitamin obtained in the present investigation are an indication that the fruits are good sources of vitamins and underline their significance nutritionally in the diet. However, low values were observed for vitamin D, B1 and B2. This could be attributed to variations in different cultivars of the fruits and the prevailing environmental conditions of cultivation. Moreover, the result revealed that there could be supplementation in the vitamin composition of the fruits when combined in right proportion in the diet, hence an indication of good mixed fruit diet.

\section{CONCLUSION}

Conclusively the present study has revealed that the organisms isolated are associated with plant materials and the fruits are sources of good nutrition and vitamins. Therefore, adequate preservative methods need to be taken to avoid their wastage as a result of spoilage.

\section{ACKNOWLEDGMENT}

The authors wish to appreciate the effort of Mr. Arukwe, U. I. in the analysis of the samples.

\section{REFERENCES}

[1] M. E. Obaedo and M. J. Ikenebomeh, "Microbiology and production of banana (Musa sapientum) wine," Nigerian Journal of Microbiology, vol. 23, no. 1, pp. 1886-1891, 2009.

[2] P. J. Akubor, S. O. Obio, K. A. Nwadomere, and E. Obiomah, "Production and quality evaluation of banana wine," Plant Food for Human Nutrition, vol. 58, pp. 1-6, 2003.

[3] G. E. Nwafia and P. Ojimelukwu, "Variability in proximate, mineral and vitamin content of Carica papaya (L.) leaves, fruit pulp and seeds," International Journal of Medicinal and Aromatic Plants, vol. 2, no. 1, pp. 90-96, 2012.

[4] M. A. Pillay, A. Tenkouano, G. Ude, and R. Irtiz, "Molecular characterization of genomes in Musa and its application," in Banana Improvement: Cellular Molecular Biology and Induced Mutations, S. M. Jain and R. Swannen, Eds., Science Publishers Inc., Enfield (NH), USA, 2004, ch. 2, pp. 124-185.

[5] S. C. Nelson, R. C. Ploetz, and A. K. Kepler, (2006). Musa species (bananas and plantains). Permanent agricultural resource, Holuoa Hawaii. [Online]. Available: http://www.agroforestory.net/tti/musabanana-plantain/ 12/06/2012.

[6] M. Pillay and L. Tripathi, "Banana," in Genome Mapping and Molecular Breeding in Plants, Fruits and Nuts, C. Kole, Ed., Springer, Varlay Berlin, 2007, vol. 4, ch. 12, pp. 281-301.

[7] M. M. Wall, "Ascorbic acid, vitamin A and mineral composition of banana (Musa spp.), papaya (Carica papaya) cuttivars grown in Hawaii," Journal of Food Composition and Analysis, vol. 19, no. 5, pp. 434-445, 2006

[8] L. M. Souza, K. S. Ferreira, J. B. Chaves, and S. L. Teixeira, "LAscorbic Acid, $\beta$-Carotene and Lycopene content in Papaya fruits (Carica Papaya) with or without physiological skin freckles," Science and Agriculture (Piracicaba, Brazil), vol. 65, no. 3, pp. 246-250, 2008.

[9] G. B. Kalou, A. Kimbononila, J. M. Nzikou, F. B. G. Po, F. E. Moutoula, E. P. Akdowa, T. H. Siliou, and S. Desoby, “ Extraction and characterization of seed oil," Agricultural Science, vol. 3, no, 2, pp. 132-137, 2011.

[10] S. Awe, "Production and microbiology of pawpaw (Carica papaya L) wine," Current Research Journal of Biological Sciences, vol. 3, no. 5, pp. 443-447, 2011

[11] A. Koocheki, S. M. A. Razavi, E. Milain, T. M. Moghadam, N. Abedin, S. Alamatiyan, and S. Izadkhah, "Physical properties of watermelon seed as a function of moisture content and variety," International Agrophysics, vol. 21, pp. 349-359, 2007.

[12] O. L. Enukainure, O. V. Oke, A. O. Daramola, S. O. Adenekan, and E. E. Umanhonlem, "Improvement of biochemical properties ofwatermelon rinds subjected to Saccharomyces cerevisiae solid 
media fermentation," Pakistan Journal of Nutrition vol. 9, no. 8, pp. 806-809, 2010

[13] P. P. Veazie and J. K. Collins, "Flesh quality and lycopene stability of fresh-cut watermelon," Postharvest Biology and Technology, vol. 31, pp. 159-166, 2004

[14] J. K. Collins, A. R. Davis, P. M. P. Veazie, and E. Adams, "Sensory evaluation of low sugar watermelon by consumers," Horticultural Science, vol. 40, pp. 883, 2005.

[15] F. I. Onyeleke and A. M. Olaniyan, "Extraction of juice from some tropical fruits using a small scale multi fruit juice extractor," African Crop Science Proceedings, vol. 8, pp. 1803-1808, 2007.

[16] J. A. Barnett, R. W. Payne, and D. Yarrow, Yeast Characterization and Identification, $3^{\text {rd }}$ ed., Cambridge University Press, USA, 2000, ch. 3, pp. 11-39.

[17] C. C. Isitua and I. N. Ibeh, "Novel method of wine production from Banana (Musa acuminata) and Pineapple (Ananas cosmosus) waste," African Journal of Biotechnology, vol. 9 no. 44, pp. 75217524, 2010.

[18] M. O. Fawole and B. A. Oso, "Laboratory manual of microbiology," Spectrum Books Limited, Ibadan, 1988, ch. 2, pp. 21-24.

[19] H. C. Okereke and I. J. Kanu, "Identification and characterization of microorganisms," in Laboratory Guide for Microbiology, A. Onyeagba, Ed., Crystal Publishers, Okigwe, 2004, ch. 4, 95-110.

[20] J. D. McClements, "Analysis of food products," Food Science vol. 581, pp. 1-57, 2003.

[21] E. I. Akubugwo and U. I. Arukwe, Basic Ouantitation Analysis of Biomacromolecules and Introductory Enzymology, Crystal Publishers, Okigwe, 2006, ch. 8, pp. 11-209.

[22] I. Amin and S. F. Cheah, "Determination of vitamin C, $\beta$-carotene and riboflavin contents in five green vegetables organically and conventionally grown," Malaysian Journal of Nutrition, vol. 9, no. 1, pp. 31-39, 2003.

[23] J. Stevens and D. Dowell, "Determination of vitamins D2 and D3 in infant formula and adult nutritionals by Ultra-Pressure Liquid Chromatography with Tandem Mass Spectrometry Detection (UPLCMS/MS)," Journal of AOAC International, vol. 95, no. 3, pp. 1-6, 2012.

[24] AOAC, Official Methods of Analysis, 18th ed., Association of Officia Analytical Chemists; Gaithersburg, MD, USA, 2005, pp. 1-34.

[25] AOAC International, Official Methods of Analysis, 15th ed., Arlington, VA, USA, 1990, pp. 1-22.

[26] C. A. Chilaka, N. Uchechukwu, J. E. Obidiegwu, and O. B. Akpor, "Evaluation of the efficiency of yeast isolates from palm wine in diverse fruit wine production," African Journal of Food Science, vol. 4, no. 12, pp. 764-774, 2010 .

[27] L. M. Prescott, T. P. Harley, and D. A. Klein, Microbiology, 7th ed., McGraw Hill, New York, 2008, pp. 956.

[28] OECD (Organization for Economic Cooperation and Development) "Consensus document on compositional considerations for new varieties of papaya (Carica papaya L.)," Key Food and Feed Nutrients, Antinutrients, Toxicant and Allergens Series of the Safety of Novel Foods and Feed, vol. 28, no. 21, pp. 1-40, 2010.

[29] G. O. Oliu, I. O. Serrano, R. S. Fortuny, and O. M. Belloso, "Effects of high-intensity pulsed electric field processing conditions on lycopene, vitamin $\mathrm{C}$ and antioxidant capacity of watermelon juice," Food Chemistry, vol. 115, pp. 1312-1319, 2009.

[30] H. M. Inuwa, V. O. Aina, B. Gabi, I. Aimola, and V. Thompson "Determination of differences in nutrient composition of Citrullus vulgaries (Water Melon) fruits after plucking," British Journal of Dairy Sciences, vol. 2, no. 2, pp. 27-30, 2011.

[31] G. E. Nwofia and Q. U. Okwu, "Studies on nutritive characteristics and variability in pawpaw (Carica papaya L.)," Pakistan Journal of Nutrition, vol. 11, no. 10, pp. 859-864, 2012.

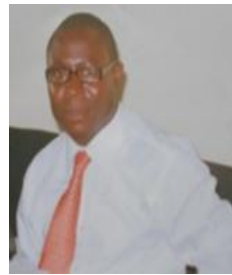

Ositadinma Chinyere Ugbogu received B.Sc and $\mathrm{PhD}$ degrees from Abia state University in 1998 and 2008 respectively. He also has an M.Sc degree in Industrial Microbiology from Michael Okpara University of Agriculture Umudike in 2005.

He taught microbiology in Abia State University Uturu before joining the Federal University Wukari as the pioneer head of Department of Microbiology. He has published scholarly articles in both local and international journals.

Dr. Ugbogu is a very active member of the Nigerian Society for Microbiology and has served as the society's business manager and currently a financial secretary.

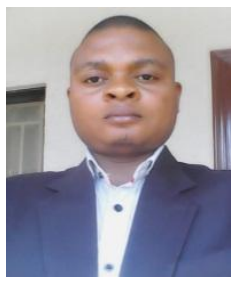

Alloysius Chibuike Ogodo holds bachelor of science (B.Sc.) in microbiology and master of science (M.Sc.) in industrial microbiology from Abia State University, Uturu and is currently a Ph.D. student in industrial microbiology.

$\mathrm{He}$ is a lecturer in microbiology at Federal University, Wukari, Taraba State, Nigeria and Student Industrial Work Experience Scheme (SIWES) representative of the Department. He is a reviewer of several international peer review journals and has several publications in both local and international journals to his credit. His research interests are in the areas of microbiology includes food and industrial as well as environmental/public health microbiology.

Mr. Ogodo is a member of the Nigerian Society for Microbiology (NSM), National Academy for the Advancement of Science (NAAS) and Nigerian Institute of Management (NIM). He is currently the staff adviser to the Nigeria Association of Microbiology Students (NAMS). 